\title{
Elevated Birth Rates in CD62L (L-Selectin)-Deficient BALB/c Mice: Potential Involvement of NK Cells
}

\author{
Balint Farkas ${ }^{1,2,3 * \#, ~ J o z s e f ~ B o d i s ~}{ }^{1,3}$, Aaron R. Mangold4, Adrienn Angyal5, \\ Ferenc Boldizsar', Katalin Mikecz², Tibor T. Glant ${ }^{2}$ \\ ${ }^{1}$ Department of Obstetrics and Gynecology, University of Pecs, Clinical Center, Pécs, Hungary \\ ${ }^{2}$ Section of Molecular Medicine, Department of Orthopedic Surgery, Biochemistry, Internal Medicine \\ (Section of Rheumatology) at Rush University Medical Center, Chicago, USA \\ ${ }^{3}$ Janos Szentagothai Research Centre, University of Pecs, Pécs, Hungary \\ ${ }^{4}$ Department of Dermatology, Mayo Clinic, Scottsdale, USA \\ ${ }^{5}$ Department of Cardiovascular Science, University of Sheffield, Sheffield, UK \\ ${ }^{6}$ Department of Immunology and Biotechnology, University of Pecs, Pécs, Hungary \\ Email: ${ }^{\#}$ dr.balint.farkas@gmail.com, bodisj@freemail.hu, aaron.mangold@gmail.com, \\ a.angyal@Sheffield.ac.uk, boldizsar.ferenc@pte.hu, katalin mikecz@rush.edu, tibor glant@rush.edu
}

Received 21 August 2014; revised 21 September 2014; accepted 21 October 2014

Copyright (C) 2014 by authors and Scientific Research Publishing Inc.

This work is licensed under the Creative Commons Attribution International License (CC BY).

http://creativecommons.org/licenses/by/4.0/

c) (7) Open Access

\section{Abstract}

Background: L-selectin (CD62L) is a cell surface adhesion molecule recently shown to play a critical role in determining endometrial receptivity and implantation in humans. By contrast, the Lselectin ligand is missing from the rodent endometrium. Interestingly, CD62L (L-selectin)-deficient BALB/c mice delivered significantly higher numbers of viable offspring than wild type controls via mechanisms yet to be defined. Methods: Nulliparous CD62L-deficient (8 - 10-week-old, $n=$ $25)$ or wild type $(n=18)$ females were mated with 43 age-matched males. Animals were sacrificed at gestational day (GD) 9.5. Tissue samples were analyzed by immunostaining and flow cytometry. Results: Mating wild type and CD62L-deficient BALB/c mice revealed that the increased birth rate was due to the CD62L deficiency in females. Flow cytometric analysis demonstrated significant differences in the number of natural killer (NK) cells present in the uterus of pregnant CD62Ldeficient mice compared to controls. Immunohistochemistry confirmed NK cell accumulation at the fetal-maternal interface. Discussion: Uterine NK cells have been shown to peak at GD 8 - 10 at the fetal-maternal interface. NK cells might regulate mouse fertility rates by facilitating development of the maternal spiral arteries, thereby stimulating the formation of larger vessels that facilitate

\footnotetext{
"Members of the MTA-PTE Human Reproduction Scientific Research Group, Hungarian Academy of Sciences (MTA), Budapest, Hungary. "Corresponding author. 
intrauterine survival, however, their role is not obligate to spiral artery development. Conclusions: Diminished CD62L expression modified immune cell trafficking into the uterus of pregnant mice generating a microenvironment primarily dominated by NK cells resulting in improved embryonic survival rates.

\title{
Keywords
}

\author{
L-Selectin, Pregnancy, BALB/c, CD62L, NK Cells, Lymphocyte Homing
}

\section{Introduction}

Uterine implantation of the human embryo begins with attachment of the blastocyst to the trophoblast. Because this process occurs under conditions of shear stress it parallels leukocyte transmigration, suggesting that the molecular basis of these processes might be analogous. Numerous investigators (and our previous studies) have confirmed a key role for leukocyte (L)-selectin (CD62L) in the inflammatory processes. CD62L plays a key first step in initiating leukocyte migration from specialized blood vessels (high endothelial venules) into the lymph node parenchyma following L-selectin binding to carbohydrate rich ligands. Outside the lymph node this interaction facilitates chemokine-driven leukocyte transmigration into inflamed tissues [1]-[3]. The same L-selectin adhesion system (L-selectin and its carbohydrate rich ligands) has been implicated in initial embryo-maternal interactions [4]-[6] and L-selectin/ligand binding has been suggested to be critical to uterine trophoblast cell development [7].

Although the mouse trophectoderm expresses L-selectin, its carbohydrate rich ligands (especially sulfated carbohydrates) are missing from the murine luminar and glandular epithelium at this developmental stage suggesting that other integrins and/or adhesion molecules may play a role in mediating this interaction [7]-[10].

Recently, we found that CD62L-deficient BALB/c mice delivered unexpectedly larger litters compared to wild type (WT) BALB/c mice. This observation led us to investigate the role of L-selectin in fetal survival and implantation. Due to the lack of adhesion molecules like L-selectin critical to leukocyte migration and extravasation, the goal of the current study was to characterize the immune cells present at the fetal-maternal interface and to define potential mechanism(s) associated with increased birth rates in CD62L-deficient mice by comparing uterine tissue samples harvested during the early stages of pregnancy.

\section{Methods}

\subsection{Reagents}

All chemicals unless otherwise specified were purchased from Sigma Chemical Co. (St. Louis, MO) or Fischer Scientific (Chicago, IL). Phosphate-buffered saline (PBS; pH 7.4) was used for washing and short-term storage of cells until use. Cell-surface labeling with monoclonal antibodies $(\mathrm{mAb})$ was carried out in flow cytometry wash buffer (PBS containing $0.1 \% \mathrm{NaN}_{3}$ and $0.1 \%$ bovine serum albumin).

\subsection{Mice and Tissue Collection}

This study was approved by the Institutional Animal Care and Use Committee (IACUC) at Rush University Medical Center. BALB/c mice were purchased from the Charles River Laboratories (Wilmington, MA). CD62L-deficient mice were purchased from The Jackson Laboratories and backcrossed into the BALB/c background as described earlier and housed under pathogen-free conditions [2]. A total of 43, 8 - 10-week-old WT $\mathrm{BALB} / \mathrm{c}$ female $(\mathrm{n}=18)$ mice and L-selectin-deficient female mice $(\mathrm{n}=25)$ were selected based on estrus-based vaginal smear checks conducted daily and then paired with age-matched CD62L-deficient or control WT BALB/c males. To standardize pregnancy age, males were kept only for 1 night in the breeding cages. Detection of a vaginal plug was defined as gestation day (GD) 0 . Pregnant mice were sacrificed using $\mathrm{CO}_{2}$ asphyxiation on GD 9.5 and uterine tissues harvested immediately, perfused with PBS, dissected, and digested with collagenase $\mathrm{D}(2 \mathrm{mg} / \mathrm{ml}$ in PBS). 


\subsection{Histological Procedures}

Formalin-fixed GD 9.5 implantation sites were embedded in paraffin and $7 \mu \mathrm{m}$ transverse sections were stained with hematoxylin and eosin (H \& E). The H\&E-stained sections were examined under bright-field light microscopy.

For immunofluorescence staining, tissue sections were incubated in $10 \%$ normal goat serum in PBS for 60 min and then incubated with either PE- or FITC-conjugated individual primary antibodies Abs (BD biosciences, San Jose, CA, USA) for $60 \mathrm{~min}$. The following Abs were used: anti-GR-1 (for neutrophil detection), antiMECA-32 or anti-E-selectin (for mouse endothelium detection), anti-CD3 (for T cell detection), and rat antimouse B220 (for B cell detection). For uterine NK cells, Dolichos biflorus agglutinin (DBA) lectin staining was used. Samples were washed with PBS for 30 min and analyzed under epifluorescent microscopy (Nikon, Microphot FMX).

\subsection{Flow Cytometric Analysis of the Fetal-Maternal Interface}

Fluorochrome-labeled rat anti-mouse antibodies specific for NK cells (anti-CD3-LFA-1 $1^{+}$Thy $1.2^{+}$), granulocytes (anti-GR1, anti-CD11b, anti-F4/80), B cells (rat anti-mouse B220), and T cells (anti-CD3) were purchased from BD Biosciences (San Jose, CA). We used multicolor labeling for the simultaneous detection of cell surface molecules on cells harvested from mouse uterine tissues at GD 9.5. Samples obtained from uterine segments (conceptus) containing the developing embryo were harvested, homogenized, and then measured using a FACS Canto II flow cytometer and data analyzed using FACS DIVA software (BD Flow Cytometry Systems, San Jose, CA). Specific cell populations were expressed as the percent of total cells unless otherwise specified. Fluorescence histogram plots were used to compare mean fluorescence intensities (MFIs) of different samples and to calculate the proportion of cells staining positive.

\subsection{Statistical Analysis}

Statistical analyses were performed using IBM SPSS Statistic 20 (IBM Corporation) at the Rush University Medical Center, Chicago, USA. The comparisons were made between the four breeding groups and the mean litter sizes according to the Mann-Whitney U test. To evaluate differences between the mean number of lymphocytes localized at the uterine segments in both, wild type, and CD62L $\mathrm{L}^{-/-}$mice Kolmogorov-Smirnov nonparametric test was applied. Mean data are reported \pm standard error of the mean (SEM). Statistical significance was set at $\left({ }^{*}\right) \mathrm{p}<0.05$, or $\left(^{* *}\right) \mathrm{p}<0.1$.

\section{Results}

\subsection{Litter Numbers}

To determine whether the L-selectin deficiency in either males or females was responsible for the observed increase in litter sizes and to determine the average number of viable pups, we performed a comparative breeding analysis using 10 -week-old nulliparous $\mathrm{BALB} / \mathrm{c}$ mice. The following breeding pair combinations were established: (1) CD62L-deficient females and CD62L-deficient males ( $\mathrm{n}=14$ breeding pairs), (2) CD62L-deficient females and WT males ( $\mathrm{n}=11$ breeding pairs), (3) WT females and CD62L-deficient males $(\mathrm{n}=8$ breeding pairs), and (4) WT females and WT males ( $\mathrm{n}=10$ breeding pairs). CD62L-deficient male and CD62L-deficient female crossings produced 118 pups with an average number of $8.43 \pm 0.55$ SEM pups/litter (Figure 1). CD62L-deficient females crossed with WT males delivered 92 pups with an average number of $8.36 \pm 0.77$ SEM pups/litter (Figure 1). WT females crossed with CD62L-deficient males had 80 pups with an average number of $6.66 \pm 0.8 \mathrm{SEM}$ pups/litter (Figure 1). WT breeding pairs produced 49 pups with an average number of $6.12 \pm 0.3 \mathrm{pups} /$ litter SEM (Figure 1). We observed a statistically significant difference between the size of the litter obtained from CD62L-deficient (male $\times$ female) breeding pairs compared to WT male $\mathrm{x}$ WT female breading pairs $(\mathrm{p}<0.01)$ and WT female $\times$ CD62L-deficient male breading pairs $(\mathrm{p}<0.05)$. These data clearly demonstrated that the significantly increased litter size observed was impacted by CD62L-deficiency in females (Figure 1). Pups obtained from all breading pairs were healthy and viable and no significant differences between the weights or lengths of pups derived from any breading pairs were observed even at 3 weeks of age (Table 1). Pups obtained from all breeding pairs developed normally and were fertile 8 weeks after birth (Table 1). 


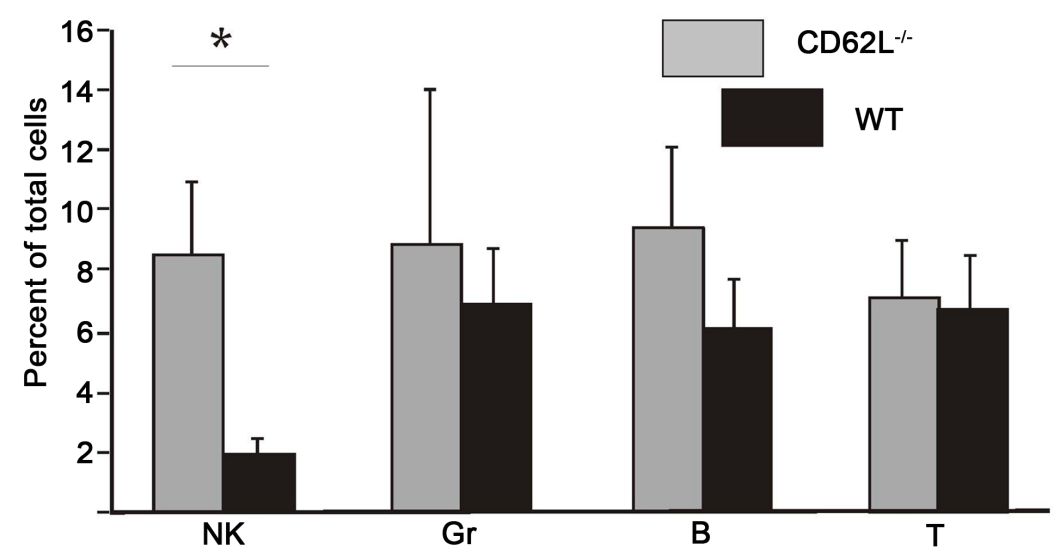

Figure 1. Average litter numbers. Columns demonstrate the mean litter numbers of viable pups, derived from four combinations of breeding pairs. Error bars represent the standard error of mean. ${ }^{*} \mathrm{p}<0.05,{ }^{* *} \mathrm{p}<0$.

Table 1. Neonatal outcome, survival rates, weights and lengths of mice.

\begin{tabular}{ccccc}
\hline Intercross & $\begin{array}{c}\text { Average newborn } \\
\text { weight }(\mathrm{g}) \pm \mathrm{SEM}\end{array}$ & $\begin{array}{c}\text { Average newborn } \\
\text { lengths }(\mathrm{cm}) \pm \mathrm{SEM}\end{array}$ & $\begin{array}{c}\text { Average 3-week-old } \\
\text { weight }(\mathrm{g}) \pm \mathrm{SEM}\end{array}$ & Fertile \\
\hline $\mathrm{CD} 2 \mathrm{~L}^{-/}$female + male & $1.22(0.34)$ & $1.89(0.64)$ & $10.78(0.87)$ & yes \\
$\mathrm{CD}^{2} \mathrm{~L}^{-/}$female + WT male & $1.16(0.28)$ & $1.94(0.38)$ & $11.82(0.78)$ & yes \\
WT female + CD62 $\mathrm{L}^{-/-}$male & $1.29(0.35)$ & $1.66(0.52)$ & $11.20(0.86)$ & yes \\
WT female + male & $1.36(0.40)$ & $1.71(0.41)$ & $12.33(1.13)$ & yes \\
\hline
\end{tabular}

\subsection{Flow Cytometric Assessment of Leukocytes Surrounding the Developing Embryos}

A profile of the type of immune cells present in uterine segments containing a developing embryo was determined at GD 9.5 in WT or L-selectin-deficient mice $(n=15)$. There were no significant differences between the number of B cells $\left(\mathrm{B}_{220^{+}}\right)$, T cells $\left(\mathrm{CD}^{+}\right)$, or activated granulocytes $\left(\mathrm{Gr}-1\right.$ high, $\left.\mathrm{CD} 11 \mathrm{~b}^{+}, \mathrm{F} 4 / 80^{+}\right)$between CD62L-deficient or WT groups (Figure 2). However, significantly higher $(\mathrm{p}<0.05)$ numbers of NK cells $\left(\mathrm{CD}{ }^{-} \mathrm{LFA1}^{+}\right.$Thy $1.2^{+}$) were present at the fetal-maternal interface of CD62L-deficient females compared to those observed in WT mice (Figure 2).

\subsection{Immunhistochemical Analysis of Leukocytes in GD 9.5 Uterine Samples}

Immunohistochemical analysis of GD 9.5 uterine samples supported the flow cytometric data presented in this study and observations previously described by others [11]-[14]. T and B cells were present at low numbers at the fetal-maternal interface and around the yolk sack. Active granulocytes (important effector cells affecting fetal loss or survival) were present at similar levels in both $\mathrm{CD} 62 \mathrm{~L}^{-/-}$and WT BALB/c female mice (data not shown). Unfortunately, due to the anatomy of the placenta, it was impossible to assess whether these cells were located intra or extravascularly. NK cells in L-selectin-deficient mice localized primarily to the decidua basalis in greater numbers than observed in WT animals (Figure 3).

\section{Discussion}

The present study was designed to determine why BALB/c mice genetically deficient for L-selectin delivered significantly higher numbers of viable pups compared to WT controls. To explain this interesting phenomenon, the study focused on identifying the potential immunological differences between WT and L-selectin knock-out mice at their respective implantation sites. Analysis of cell populations at the fetal-maternal interface at GD 9.5 identified significant differences in NK cell numbers between WT and CD62L-deficient BALB/c mice.

L-selectin and its ligands have been shown to play critical roles in the homing, attachment, and tethering of 


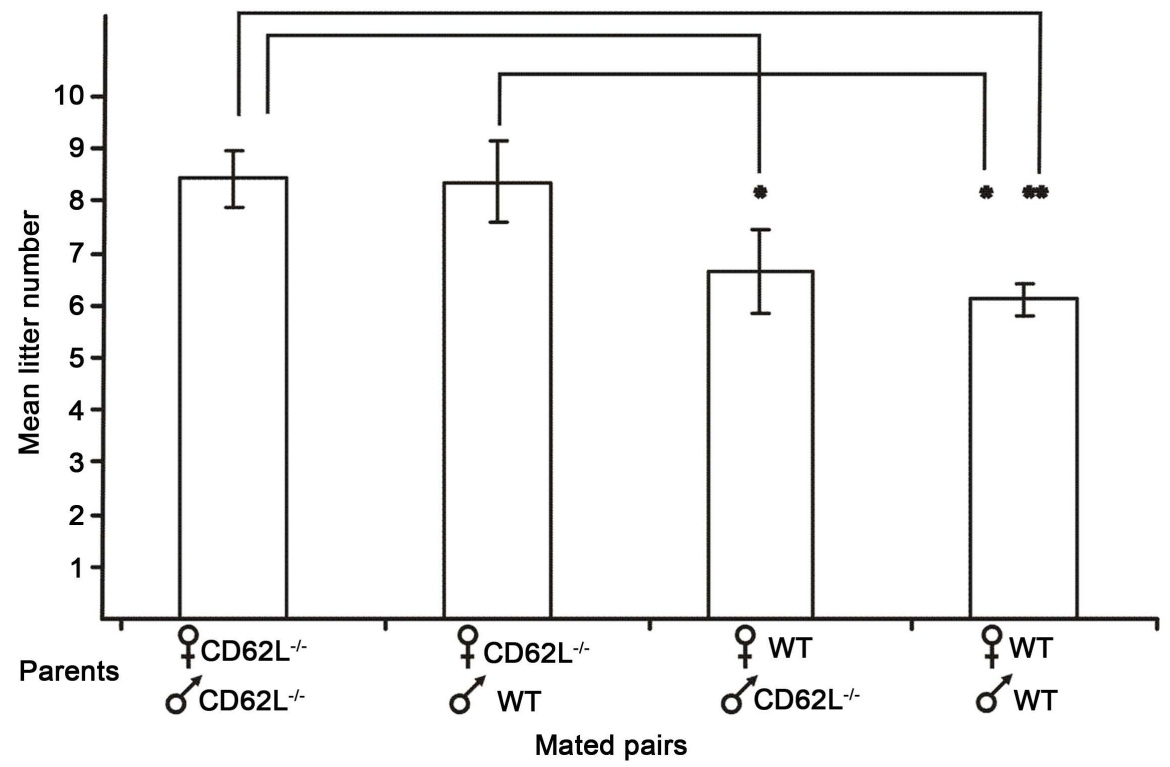

Figure 2. Uterine leukocyte composition at GD 9.5 in both CD62L $\mathrm{L}^{-/-}$and WT BALB/c mice. Uterine samples harvested on GD $9.5(n=15)$ were minced in PBS. Each developing embryo was homogenized in the presence of collagenase $\mathrm{D}$, allowed to digest, labeled with various fluorescent monoclonal antibodies, and analyzed by FACS. Cell groups were defined as follows: NK cells $\left(\mathrm{CD} 3^{-} \mathrm{LFA} 1^{+}\right.$Thy1.2 $\left.2^{+}\right)$; granulocytes $\left(\mathrm{Gr}-1^{+} \mathrm{CD} 11 \mathrm{~b}^{+} \mathrm{F} 4 / 80^{+}\right)$; B cells $\left(\mathrm{B} 220^{+}\right)$, and $\mathrm{T}$ cells $\left(\mathrm{CD} 3^{+}\right)$. Light grey columns represent CD62L-deficient mice and the dark grey bars represent WT animals $(\mathrm{p}<0.05)$.
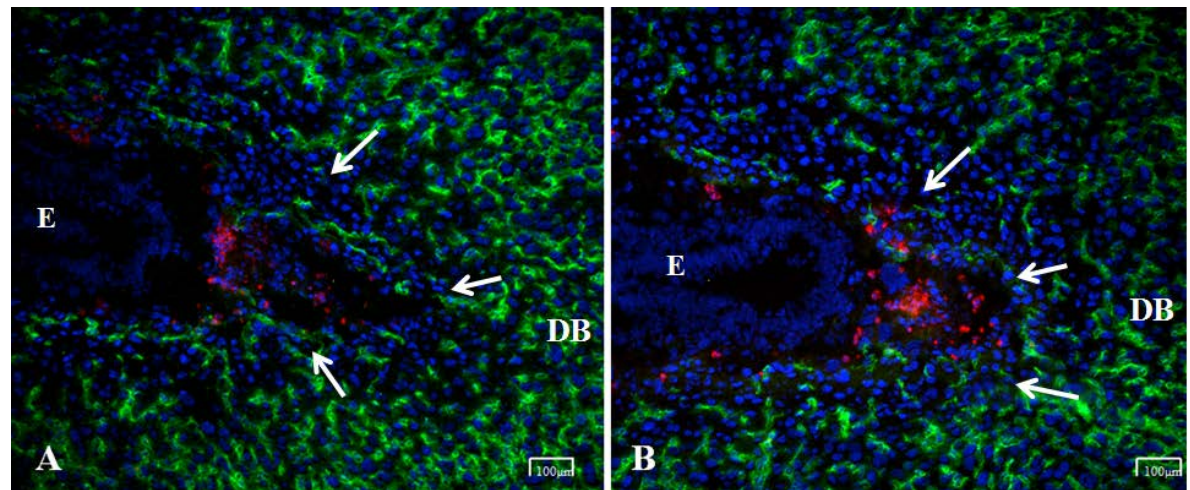

Figure 3. Immunohistochemical analysis of the uterus at GD 9.5. Tissues were stained with DBA lectin specific for uterine NK cells (red) and a MECA-32 monoclonal antibody (vascular zone endothelium - green) followed by DAPI staining (nuclei of the trophoblast cells-blue). Samples were analyzed under epifluorescent light microscopy and images overlaid. Uterus at GD 9.5 from WT (A) and $\mathrm{CD}_{2} \mathrm{~L}^{-/-} \mathrm{BALB} / \mathrm{c}$ mice (B). NK cells (red) localized only at the mesometrial side of the implantation sites (E-embryo), at the decidua basalis (DB), in both images (20× magnification). The DBA positivity reactions were localized to cell surface and to the cytoplasmic granules. Staining intensity reveals accumulation of NK cells in the right image (B). Arrows indicate the exact localization of the cumulating NK cells in both L-selectin ligand deficient and wild type mice, as detected with immunostaining abovementioned.

immune cells to the extracellular matrix of both humans and mice [15] [16]; however, in the present study migration/trafficking analyses were not performed. Therefore, until a bone marrow transplant between a CD62L $\mathrm{L}^{-/}$

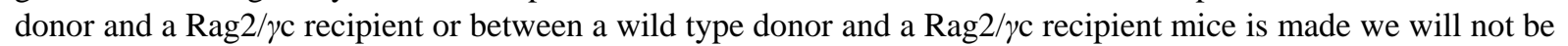
able to determine whether immune cell recruitment was higher in CD62L deficient mice. This is the subject of future experiments. 
Several previous studies reported that L-selectin ${ }^{-/-}$mice had a significantly increased total number of splenic lymphocytes (including B and T cells) that comprised up to 30\% - 55\% of the spleen cell population [17]-[19]. NK cells also localized to the spleen of these mice forming around $12 \%$ of all nucleated cells present in the red pulp [20]-[22]. In contrast, no change in the number of either B lymphocytes or NK cells in the has been reported to date in CD62L $\mathrm{L}^{-/}$mice [17].

NK cells represent approximately $10 \%$ of the leukocyte population in both humans and mice [23]. In humans, NK cell subpopulations can be identified based on cell surface expression of CD3, CD16, and CD56; accounting for 3 distinct NK cell subtypes: (1) CD56 ${ }^{\text {dim }} \mathrm{CD} 16^{+}$(representing about $90 \%$ of all NK cells), (2)

CD56 $6^{\text {bright }} \mathrm{CD} 16^{\mathrm{dim}}$, and (3) $\mathrm{CD}^{+} \mathrm{CD} 56^{+}$[24]-[26]. Direct lysis of target cells is the primary effector function for CD56 ${ }^{\text {dim }}$ NK cells, conversely, effector functions for CD56 ${ }^{\text {bright }}$ NK cells involves immune regulation [27]. On the other hand, only two populations of NK cells have been described in mice and characterized based on their CD11 (CD11 $b^{\text {low }}$ and CD11 ${ }^{\text {high }}$ ) expression levels. The CD11 ${ }^{\text {high }}$ NK cell population can be further categorized into 2 subsets: the $\mathrm{CD} 11 \mathrm{~b}^{\text {high }} \mathrm{CD} 27^{\text {high }}$ and the $\mathrm{CD} 11 \mathrm{~b}^{\text {high }} \mathrm{CD} 27^{\text {low }}$ cells [28]. Uterine NK (uNK) cells represent a unique group of NK cells in both species, but their exact place among NK cell types is incompletely understood in mice. In humans, however, uNK cells (CD56 ${ }^{\text {bright }}$ ) can be detected during menstrual cycles in contrast to their mouse analogs that can only be identified by DBA staining after blastocyst implantation [29].

Using mice lacking lymphocytes (RAG- ${ }^{-/}$), 3 uNK functions were identified as follows: 1 ) support of terminal decidual cell differentiation, 2) sensitization of spiral arteries resulting in pregnancy-associated dilation and elongation, and 3) formation of a transient lymphoid aggregates at the portal vessels and nerves serving as implantation sites [30] [31]. On the other hand, NK cell-deficient mice remained fertile and delivered normal numbers of viable pups, suggesting that NK cells may not be essential to healthy pregnancies in mice even though significant differences exist between the MLAp (mesometrial lymphoid aggregate of pregnancy) of NK cell-deficient mice and WT animals [32]. Nevertheless, the importance of uNK cells in driving the maturation of uterine spiral arteries into bigger caliber vessels suggested that uNK cells were indeed important to normal pregnancy development since they significantly affected the decidualization and vascularization processes.

Most animal pregnancy models have been designed (by crossing genetically well-defined inbred mouse strains such as C57BL6 and DBA/2) to study mechanisms associated with fetal loss and pregnancy-associated pathologies [13]. This approach thereby mimics the semi-allogeneic graft status of the embryo. In contrast, the present study used an inbred (BALB/c background) colony that allowed us to investigate the specific role of CD62L during pregnancy independent of maternal-paternal MHC gene differences. Although the similarity at the MHC locus in inbred BALB/c mice could eliminate the semi-allogenic graft phenomenon, it could not explain the increase in the number of littermates delivered by CD62L-deficient females.

Based on our observations (and data available in the literature) it is unlikely that NK cells alone accounted for the increase in the number of pups born from $\mathrm{CD}_{2} \mathrm{~L}^{-/-}$female BALB/c mice. Another possible explanation could be that CD62L-deficient mice presented with alterations in the IL-15 and IFN- $\gamma$ cytokine signaling pathways [33] [34] (that affect uNK cell proliferation) resulting in a significantly altered micro environment at the fetal-maternal interface favoring fetal development resulting in larger litters. This could occur via different mechanisms, for example, by preventing homing of NK cells into the decidua, affecting their effector functions (making these cells more regulatory in nature), or by preventing pro-uNK cell trafficking from LNs into the pregnant uterus.

\section{Conclusion}

The increased size in the litters of $\mathrm{CD}_{2} 2 \mathrm{~L}^{-/-} \mathrm{BALB} / \mathrm{c}$ mice was due to changes affecting female mice. Immunological analyses revealed significantly elevated numbers of NK cells in the uteri of CD62 $\mathrm{L}^{-1-}$ animals that could have influenced the uterine microenvironment early in pregnancy and played a critical role in regulating maternal tolerance, consequently leading to the delivery of a greater number of viable pups.

\section{Competing Interests}

The authors report no conflicts of interest regarding the data presented in this report.

\section{Authors' Contributions}

BF and TTG made substantial contributions to the conception and the design of the study. AM and BF carried 
out the histopathologic and immunohistochemical analysis and BF also participated in data acquisition and in the pathologic assessment. AA carried out the flow cytometric analysis, mouse breeding, and statistical analysis. JB and FB participated in the design of the study and in drafting the manuscript. KM conceived the study, participated in its design and coordination, helped draft the manuscript, backcrossed CD62L $\mathrm{L}^{-1-}$ mice into BALB/c background, and provided the animals for the study. All authors read and approved the final version of the manuscript submitted for publication.

\section{Acknowledgements}

We wish to thank the staff of the Comparative Research Center at Rush University Medical Center, Chicago, IL, USA. We would like to thank Dr. Oktavia Tarjanyi for her help in the breeding of mice and in the immunostaining procedures. This work was supported in part by the National Institutes of Health Grant (NIH; AR045652), The J.O. Galante Endowment Chair (Rush University Medical Center, Chicago, IL, 60612), and project SROP-4.2.2.A-11/1/KONV-2012-0053 "Investigation of biomarkers in culture medium for the success rate of in vitro fertilization".

\section{References}

[1] Sarraj, B., Ludányi, K., Glant, T.T., Finnegan, A. and Mikecz, K. (2006) Expression of CD44 and L-Selectin in the Innate Immune System Is Required for Severe Joint Inflammation in the Proteoglycan-Induced Murine Model of Rheumatoid Arthritis. Journal of Immunology, 177, 1932-1940.

[2] Szántó, S., Gál, I., Gonda, A., Glant, T.T. and Mikecz, K. (2004) Expression of L-Selectin, But Not CD44, Is Required for Early Neutrophil Extravasation in Antigen-Induced Arthritis. Journal of Immunology, 172, 6723-6734.

[3] Kawashima, H. (2006) Roles of Sulfated Glycans in Limphocyte Homing. Biological and Pharmaceutical Bulletin, 29, 2343-2349. http://dx.doi.org/10.1248/bpb.29.2343

[4] Wang, B., Sheng, J.Z., He, R.H., Qian, Y.L., Jin, F. and Huang, H.F. (2008) High Expression of L-Selectin Ligand in Secretory Endometrium Is Associated with Better Endometrial Receptivity and Facilitates Embryo Implantation in Human Being. American Journal of Reproductive Immunology, 60, 127-134.

http://dx.doi.org/10.1111/j.1600-0897.2008.00604.x

[5] Alon, R. and Feigelson, S. (2002) From Rolling to Arrest on Blood Vessels: Leukocyte Tap Dancing on Endothelial Integrin Ligands and Chemokines at Sub-Second Contacts. Seminars in Immunology, 14, 93-104.

http://dx.doi.org/10.1006/smim.2001.0346

[6] Rosen, S.D. (2004) Ligands for L-Selectin: Homing, Inflammation, and Beyond. Annual Review of Immunology, 22, 129-156. http://dx.doi.org/10.1146/annurev.immunol.21.090501.080131

[7] Genbacev, O.D., Prakobphol, A., Foulk, R.A., Krtolica, A.R., Ilic, D., Singer, M.S., Yang, Z.Q., Kiessling, L.L., Rosen, S.D. and Fisher, S.J. (2003) Trophoblast L-Selectin-Mediated Adhesion at the Maternal-Fetal Interface. Science, 299, 405-408. http://dx.doi.org/10.1126/science.1079546

[8] Foulk, R.A., Zdravkovic, T., Genbacev, O. and Prakobphol, A. (2007) Expression of L-Selectin Ligand MECA-79 as a Predictive Marker of Human Uterine Receptivity. Journal of Assisted Reproduction and Genetics, 24, 316-321. http://dx.doi.org/10.1007/s10815-007-9151-8

[9] Wang, B., Sheng, J.Z., He, R.H., Qian, Y.L., Jin, F. and Huang, H.F. (2008) High Expression of L-Selectin Ligand in Secretory Endometrium Is Associated with Better Endometrial Receptivity and Facilitates Embryo Implantation in Human Being. American Journal of Reproductive Immunology, 60, 127-134. http://dx.doi.org/10.1111/j.1600-0897.2008.00604.x

[10] Nejatbakhsh, R., Kabir-Salmani, M., Dimitriadis, E., Hosseini, A., Taheripanah, R., Sadeghi, Y., Akimoto, Y. and Iwashita, M. (2012) Subcellular Localization of L-Selectin Ligand in the Endometrium Implies a Novel Function for Pinopodes in Endometrial Receptivity. Reproductive Biology and Endocrinology, 10, 46-54. http://dx.doi.org/10.1186/1477-7827-10-46

[11] Croy, B.A., Zhang, J., Tayade, C., Colucci, F., Yadi, H. and Yamada, A.T. (2010) Analysis of Uterine Natural Killer Cells in Mice. Methods in Molecular Biology, 612, 465-503. http://dx.doi.org/10.1007/978-1-60761-362-6 31

[12] Korrick, S.A., Chen, C., Damokosh, A.I., Ni, J., Liu, X., Cho, S.I., Altshul, L., Ryan, L. and Xu, X. (2001) Association of DDT with Spontaneous Abortion: A Case-Control Study. Annals of Epidemiology, 11, 491-496. http://dx.doi.org/10.1016/S1047-2797(01)00239-3

[13] Girardi, G. (2008) Guilty as Charged: All Available Evidence Implicates Complement’s Role in Fetal Demise. American Journal of Reproductive Immunology, 59, 183-192. http://dx.doi.org/10.1111/j.1600-0897.2007.00572.x 
[14] Holers, V.M., Girardi, G., Mo, L., Guthridge, J.M., Molina, H., Pierangeli, S.S., Espinola, R., Xiaowei, L.E., Mao, D., Vialpando, C.G. and Salmon, J.E. (2002) Complement C3 Activation Is Required for Antiphospholipid AntibodyInduced Fetal Loss. Journal of Experimental Medicine, 195, 211-220. http://dx.doi.org/10.1084/jem.200116116

[15] Steeber, D.A. and Tedder, T.F. (2000) Adhesion Molecule Cascades Direct Lymphocyte Recirculation and Leukocyte Migration during Inflammation. Immunologic Research, 22, 299-317. http://dx.doi.org/10.1385/IR:22:2-3:299

[16] Grailer, J.J., Kodera, M. and Steeber, D.A. (2009) L-Selectin: Role in Regulating Homeostasis and Cutaneous Inflammation. Journal of Dermatological Science, 56, 141-147. http://dx.doi.org/10.1016/j.jdermsci.2009.10.001

[17] Lejtenyi, D., Osmond, D.G. and Miller, S.C. (2003) Natural Killer Cells and B Lymphocytes in L-Selectin and Mac-1/LFA-1 Knockout Mice: Marker-Dependent, but Not Cell Lineage-Dependent Changes in the Spleen and Bone Marrow. Immunobiology, 207, 129-135. http://dx.doi.org/10.1078/0171-2985-00220

[18] Arbones, M.L., Ord, D.C., Ley, K., Ratech, H., Maynard-Curry, C., Otten, G., Capon, D.J. and Tedder, T.F. (1994) Lymphocyte Homing and Leukocyte Rolling and Migration Are Impaired in L-Selectin (CD62L) Deficient Mice. Immunity, 1, 247-260. http://dx.doi.org/10.1016/1074-7613(94)90076-0

[19] Tedder, T.F., Steeber, D.A., Chen, A. and Engel, P. (1995) The Selectins: Vascular Adhesion Molecules. FASEB Journal, 9, 866-873.

[20] van den Brink, M.R.M., Palomba, M.L., Basse, P.H. and Hiserodt, J.C. (1991) In Situ Localization of 3.2.3.+ Natural Killer Cells in Tissues from Normal and Tumor-Bearing Rats. Cancer Research, 52, 4931-4936.

[21] Allavena, P., Paganin, C., Martin-Padura, I., Peri, G., Gaboli, M., Dejena, E., Marchisio, P.C. and Mantovani, A. (1991) Molecular Structures Involved in the Adhesion of Natural Killer Cells to Vascular Endothelium. Journal of Experimental Medicine, 173, 439-448. http://dx.doi.org/10.1084/jem.173.2.439

[22] Bianchi, G., Sironi, M., Ghibaudi, E., Selvaggini, C., Elices, M., Allavena, P. and Montovani, A. (1993) Migration of Natural Killer Cells across Endothelial Cell Monolayer. Journal of Immunology, 151, 5135-5144.

[23] Erlebacher, A. (2013) Immunology of the Maternal-Fetal Interface. Annual Review of Immunology, 31, 387-411. http://dx.doi.org/10.1146/annurev-immunol-032712-100003

[24] van den Heuvel, M.J., Xie, X., Tayade, C., Peralta, C., Fang, Y., Leonard, S., Paffaro, V.A., Sheikhi, A.K., Murrant, C. and Croy, B.A. (2005) A Review of Trafficking and Activation of Uterine Natural Killer Cells. American Journal of Reproductive Immunology, 54, 322-331. http://dx.doi.org/10.1111/j.1600-0897.2005.00336.x

[25] van den Heuvel, M., Peralta, C., Bashar, S., Taylor, S., Horrocks, J. and Croy, B.A. (2005) Trafficking of Peripheral Blood CD56 ${ }^{\text {bright }}$ Cells to the Decidualizing Uterus-New Tricks for Old Dogmas? Journal of Reproductive Immunology, 67, 21-34. http://dx.doi.org/10.1016/j.jri.2005.03.004

[26] Frey, M., Packianathan, N.B., Fehniger, T.A., Ross, M.E., Wang, W.C., Stewart, C.C., Caligiuri, M.A. and Evans, S.S. (1998) Differential Expression and Function of L-Selectin on CD56bright and CD56dim Natural Killer Cell Subsets. Journal of Immunology, 161, 400-408.

[27] King, A. (2000) Uterine Leukocytes and Decidualization. Human Reproduction Update, 6, 28-36. http://dx.doi.org/10.1093/humupd/6.1.28

[28] Chiossone, L., Chaix, J., Fuseri, N., Roth, C., Vivier, E. and Walzer, T. (2009) Maturation of Mouse NK Cells Is a 4-Stage Developmental Program. Blood, 113, 5488-5496. http://dx.doi.org/10.1182/blood-2008-10-187179

[29] Zhang, J., Chen, Z., Fritz, J.H., Rochman, Y., Leonard, W.J., Gommerman, J.L., Plumb, A.W., Abraham, N. and Croy, B.A. (2012) Unusual Timing of CD127 Expression by Mouse Uterine Natural Killer Cells. Journal of Leukocyte Biology, 91, 417-426. http://dx.doi.org/10.1189/jlb.1011501

[30] Guimond, M.J., Luross, J.A., Wang, B., Terhorst, C., Danial, S. and Croy, B.A. (1997) Absence of Natural Killer Cells during Murine Pregnancy Is Associated with Reproductive Compromise in TgE26 Mice. Biology of Reproduction, 56, 169-179. http://dx.doi.org/10.1095/biolreprod56.1.169

[31] Croy, B.A., di Santo, J.P., Greenwood, J.D., Chantakru, S. and Ashkar, A.A. (2000) Transplantation into Genetically Alymphoid Mice as an Approach to Dissect the Roles of Uterine Natural Killer Cells during Pregnancy-A Review. Placenta, 21, S77-S80. http://dx.doi.org/10.1053/plac.1999.0518

[32] Guimond, M.J., Wang, B. and Croy, B.A. (1998) Engraftment of Bone Marrow from Severe Combined Immunodeficient (SCID) Mice Reverses the Reproductive Deficits in Natural Killer Cell-Deficient TgEpsilon 26 Mice. Journal of Experimental Medicine, 187, 217-223. http://dx.doi.org/10.1084/jem.187.2.217

[33] De Carolis, C., Perricone, C. and Perricone, R. (2010) NK Cells, Autoantibodies, and Immunologic Infertility: A Complex Interplay. Clinical Reviews in Allergy \& Immunology, 39, 166-175. http://dx.doi.org/10.1007/s12016-009-8184-4

[34] Ashkar, A.A., Di Santo, J.P. and Croy, B.A. (2000) Interferon $\gamma$ Contributes to Initiation of Uterine Vascular Modification, Decidual Integrity, and Uterine Natural Killer Cell Maturation during Normal Murine Pregnancy. Journal of Experimental Medicine, 192, 259-270. http://dx.doi.org/10.1084/jem.192.2.259 


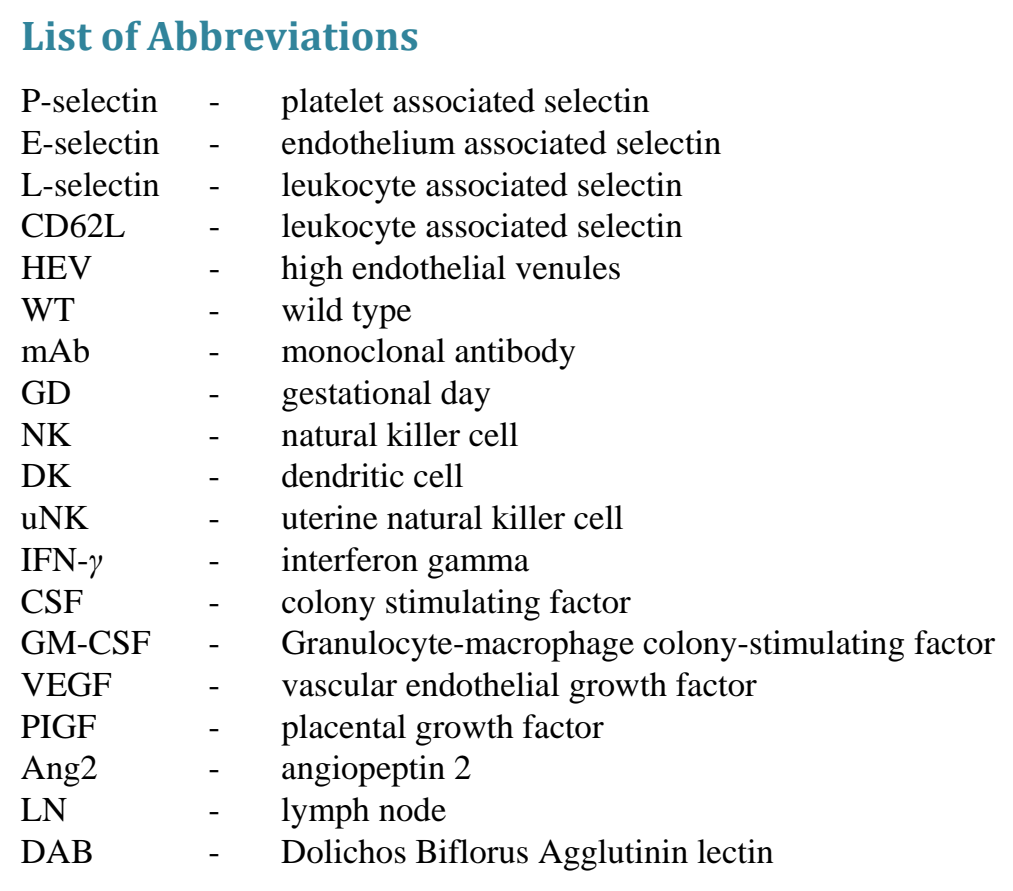


Scientific Research Publishing (SCIRP) is one of the largest Open Access journal publishers. It is currently publishing more than 200 open access, online, peer-reviewed journals covering a wide range of academic disciplines. SCIRP serves the worldwide academic communities and contributes to the progress and application of science with its publication.

Other selected journals from SCIRP are listed as below. Submit your manuscript to us via either submit@scirp.org or Online Submission Portal.
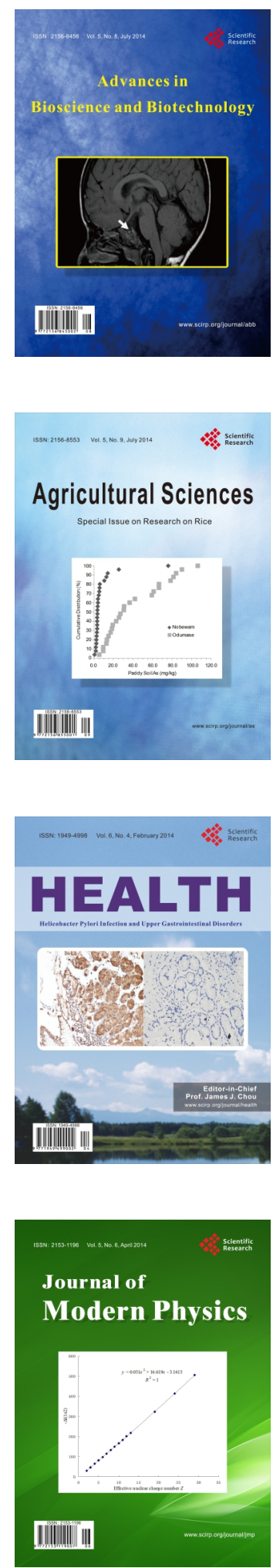
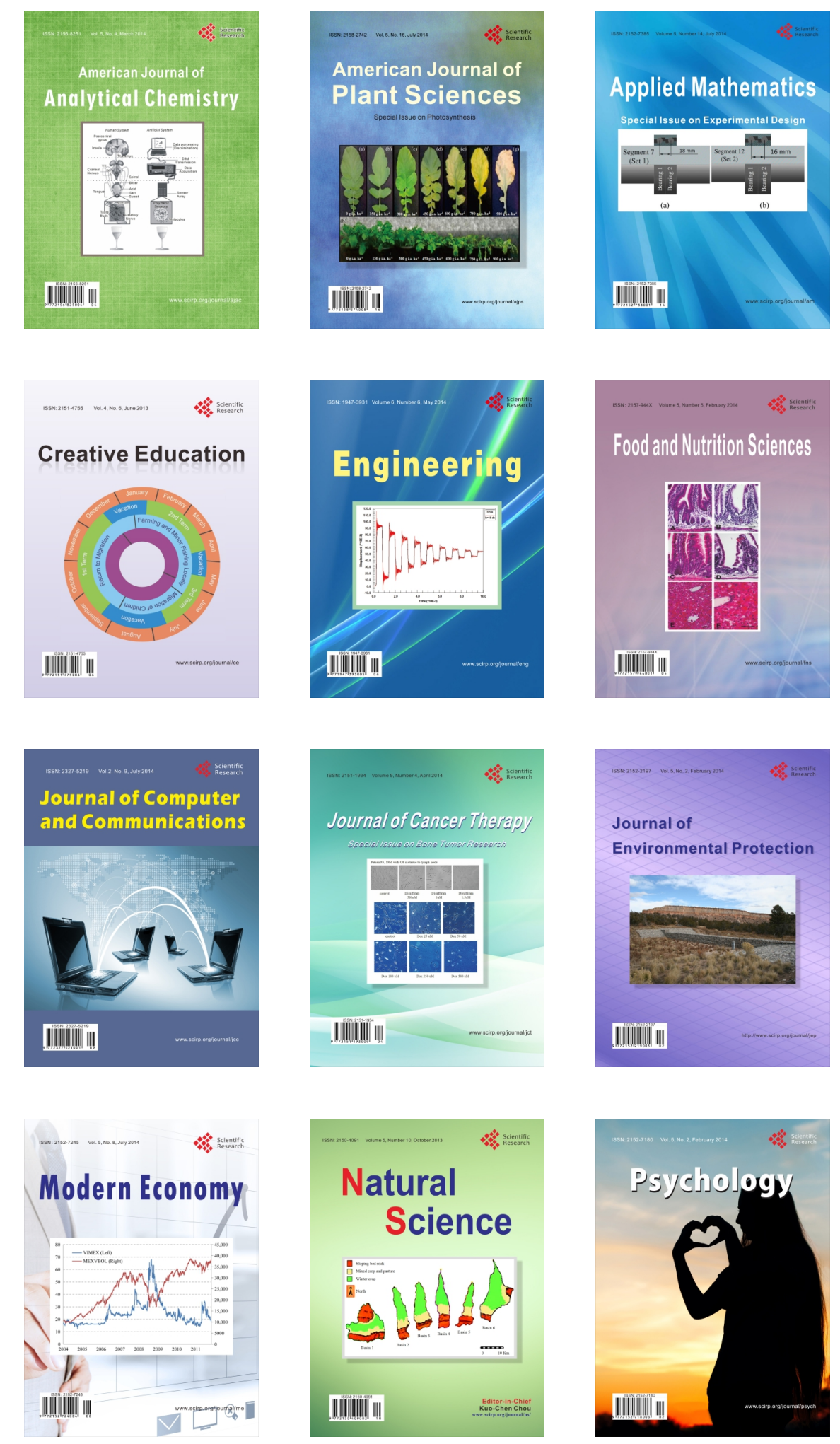